\title{
Can traditional selective logging secure tree regeneration in cloud forest?
}

\author{
Perla Ortiz-Colín ${ }^{(1)}$, \\ Tarin Toledo-Aceves ${ }^{(1)}$, \\ Fabiola López-Barrera ${ }^{(1)}$, \\ Patricia Gerez-Fernández ${ }^{(2)}$
}

\begin{abstract}
Unplanned selective logging for charcoal and firewood is a common practice in tropical montane cloud forest (TMCF), a high priority ecosystem for biodiversity conservation at the global scale. However, limited information is available regarding the impact of such logging on forest regeneration. We evaluated the abundance and composition of tree regeneration in four TMCF sites subject to traditional selective logging in southern Mexico. At each site, we calculated a tree extraction index based on the number of stumps, logs and charcoal kilns and established six $200 \mathrm{~m}^{2}$ plots where the abundance of adult, sapling and seedling trees were recorded and canopy cover estimated. Based on the extraction index and estimated basal area values, two sites each were classified as being of low $(\mathrm{L})$ and high $(\mathrm{H})$ logging intensity; the extraction index was three times lower in $L(7.5$ and 9.2) than in $\mathrm{H}$ (35 and 35$)$ sites, while basal area was significantly higher in $L$ than in $H$ sites $(80.2 \pm 10.2$ vs. $41.9 \pm 4.96$ $\mathrm{m}^{2} \mathrm{ha}^{-1}$, respectively). No significant differences were found among sites in terms of canopy cover, diameter and density of adult trees or in the density of saplings and seedlings $\left(0.72\right.$ individuals $\left.\mathrm{m}^{-2}\right)$. In all sites, species of intermediate shade-tolerance dominated the regeneration $(76 \%)$, followed by the shadetolerant $(23 \%)$ and pioneer $(1 \%)$ species. Regeneration of Quercus spp. (four species) dominated at all sites (50.5\%); this is a group of particular interest to the local communities because of its utility for firewood and charcoal. The similarity in composition between adult and regenerating tree species was relatively high in all of the sites (Morisita-Horn Index L1 $=0.86, \mathrm{~L} 2=0.64, \mathrm{H} 1=0.69$ and $\mathrm{H} 2=0.71$ ). These results indicate that, under the evaluated selective logging intensities, TMCF can sustain sufficient regeneration of Quercus spp. and thus presents an opportunity for sustainable management. The legacy effects of traditional selective logging on TMCF tree regeneration are discussed.
\end{abstract}

Keywords: Firewood, Forest Management, Mexico, Quercus, Seedlings, Timber Harvesting, Tropical Montane Cloud Forest, Disturbance

\section{Introduction}

Secondary and degraded forests currently form the dominant components in tropical landscapes, covering an area larger than that of primary forests (Chazdon 2003, FAO 2015). The degree of contribution of degraded forests to biodiversity conservation depends on the type, intensity and frequency of disturbance to which these have been subjected (Gibson et al. 2011, Putz et al. 2012). A common cause of degradation in tropical forests worldwide is selective logging to obtain timber, firewood and charcoal (Chidumayo \& Gumbo 2013). This unplanned practice consists of the isolated extraction of trees above a certain trunk diameter, and involves no measures to reduce the consequent negative impacts on diversity. Compared to other types of disturbance, such as the conversion of forest to agricultural and livestock production uses, selective logging has considerably less impact on the diversity of species in tropical forests (Gibson et

(1) Instituto de Ecología A. C., Carretera antigua a Coatepec 351, El Haya, Xalapa 91070, Veracruz (México); (2) Instituto de Biotecnología y Ecología Aplicada, Universidad Veracruzana, Zona Universitaria, Xalapa 91090, Veracruz (México)

@ Tarin Toledo-Aceves (tarintoledo@gmail.com)

Received: Dec 04, 2015 - Accepted: Oct 20, 2016

Citation: Ortiz-Colín P, Toledo-Aceves T, López-Barrera F, Gerez-Fernández P (2017). Can traditional selective logging secure tree regeneration in cloud forest? iForest 10: 369-375. doi: 10.3832/ifor1937-009 [online 2017-03-07]

Communicated by: Mike Perks

al. 2011, Carreño-Rocabado et al. 2012); however, the impacts of traditional selective logging on the regeneration of different tropical forests are poorly understood because of the particular nature of the characteristics and traditional uses in each ecosystem.

Chronic selective logging is an activity historically practiced in the tropical montane cloud forest (TMCF), one of the most threatened tropical ecosystems worldwide (Scatena et al. 2010). This ecosystem has high conservation priority status because of its high alpha and beta diversity, as well as the range of environmental services it provides (Kappelle et al. 1996, Scatena et al. 2010). The TMCF are frequently located in inaccessible gullies and on steep slopes, with trees of variable commercial quality and low productivity (Scatena et al. 2010) that present low potential for timber forestry (Toledo-Aceves et al. 2011). Nevertheless, these forests are exploited daily by local communities through unregulated traditional extraction, whose production is essentially of subsistence (Rüger et al. 2008). Despite the wide distribution of forest management practices in Mexico, there 
are no records of TMCF under authorized forest management (CONABIO 2010). In addition to other factors of change, selective logging threatens the persistence of populations of tree species that are exclusive to this ecosystem. It is estimated that more than $60 \%$ of TMCF tree species in Mexico are threatened and many of these species are affected by a decline in their natural regeneration (González-Espinosa et al. 2011).

Regeneration is a key process, since the establishment and survival of seedlings is crucial to the reproductive success and population dynamics of species. Among the main effects of selective logging is increased canopy openness, which affects germination and growth of established seedlings (Guariguata \& Pinard 1998, Kozlowski 2002, Nabe-Nielsen et al. 2007). Studies of the effect of selective logging on the diversity of tree regeneration in tropical forests under planned forestry management have produced contrasting results. While selective logging can negatively affect the diversity and regeneration of tropical and temperate forests (Farwig et al. 2008, Clark \& Covey 2012), opening of the canopy as a consequence of planned extraction can also have positive effects on the regeneration of certain timber species (Guariguata \& Sáenz 2002, Götmark 2007, Duah-Gyamfi et al. 2014). In a recent metaanalysis of tropical forests, Martin et al. (2015) found that tree richness increased with low logging intensities and vice versa. Most studies agree that selective logging has a significant influence on species composition (Decocq et al. 2014, Farwig et al. 2008), while other studies report effects on functional guilds or ecological groups (Carreño-Rocabado et al. 2012, Imai et al. 2012).

Understanding the regeneration dynamics in response to tree extraction is therefore essential for effective TMCF management. However, there are very few studies that address selective logging in TMCF and its effects on the structure and composi- tion of arboreal regeneration (Rüger et al. 2008). The objectives of this study were therefore: (i) to evaluate the extent of extraction in TMCF fragments subjected to chronic selective logging; (ii) to determine the nature of its relationship with tree structure and composition, as well as its influence on tree regeneration.

\section{Methods}

\section{Study area}

The study was conducted in the sub-basin of the River Pixquiac, within the La Antigua basin, in Veracruz, Mexico. This is a region of high priority for the conservation of TMCF (Toledo-Aceves et al. 2011). The landscape is dominated by patches of secondary and degraded TMCF, livestock pastures and agricultural land (Muñoz-Villers \& Lopez-Blanco 2008). Total annual precipitation is $1650 \mathrm{~mm}$ and the annual average temperature is $14^{\circ} \mathrm{C}$ (Williams-Linera 2002). Selective extraction of trees in this region varies in intensity and frequency, but it is a widely distributed practice that follows no planned method. Trees $\geq 40 \mathrm{~cm}$ in diameter and species of high dendroenergetic value are selected for extraction. These mainly belong to the genus Quercus and are mainly used to produce firewood and charcoal (Haeckel 2006). In order to produce charcoal, logs are cut within the forest and processed in rudimentary kilns constructed in the forest soil.

\section{Site selection and degree of extraction}

In order to evaluate the status of regeneration with selective logging, four TMCF sites were chosen with a history of frequent selective logging over recent decades, but with no other form of disturbance (e.g., grazing in the forest, fires, introduction of exotic species - Tab. 1). Since no undisturbed forests were present within the study area (due to selective logging or other perturbations, such as grazing and unpaved forest roads), it was not possible to select a control treatment as reference. In the studied forests, clandestine tree extraction continues to occur with no authorization from the landowners. Analysis of panchromatic aerial photographs (1975, 1995 and 2004 - 1:20.000 scale, INEGI) confirmed that the four study sites had maintained continuous forest cover over the preceding 40 years. Slope varied from 58 to $69 \%$ among the sites.

An extraction index (modified from Ramírez-Marcial et al. 2001) was developed in order to characterize each site. An area of $\sim 1.2$ ha within and around the vegetation measurement plots (described below) was examined, and the numbers of tree stumps, logs and charcoal kilns recorded. Tree stump diameter was measured at the base (10 $\mathrm{cm}$ above ground level).

\section{Woody vegetation and canopy coverage}

In each site, six plots of $10 \times 20 \mathrm{~m}\left(200 \mathrm{~m}^{2}\right)$ were established at least $15 \mathrm{~m}$ far from the edge of the forest fragment and were distributed equidistantly. In each plot, the diameter at breast height (DBH, $1.3 \mathrm{~m}$ above the ground) of all trees with $\mathrm{DBH} \geq$ $10 \mathrm{~cm}$ was recorded, while the height of the five trees with the largest trunks was determined with a clinometer. A subplot of $5 \times 5 \mathrm{~m}\left(25 \mathrm{~m}^{2}\right)$ was randomly established in one of the corners of each $200 \mathrm{~m}^{2}$ plot in order to record all saplings $>1 \mathrm{~m}$ in height and $<10 \mathrm{~cm}$ DBH. The height and DBH values of all the individual saplings were recorded. In addition, four subplots of $1 \times 1 \mathrm{~m}$ were established along the central axis of each $200 \mathrm{~m}^{2}$ plot (two at each side in an alternating pattern) in order to record tree seedlings $>0.2 \mathrm{~m}$ and $\leq 1 \mathrm{~m}$ in height. The 1 $\mathrm{m}^{2}$ subplots were located at a distance of 3 $\mathrm{m}$ from the extremes of the plot and were equidistantly distributed. Maximum seedling height and stem basal diameter were recorded. In order to evaluate the relationship between canopy coverage and regeneration, the canopy coverage in the center of each $1 \mathrm{~m}^{2}$ plot was measured with a convex densiometer.

Tab. 1 - Cloud forest structural variables (mean \pm standard error) and tree diversity in sites with low (L1 and L2) and high (H1 and $\left.\mathrm{H}_{2}\right)$ selective logging intensities in Veracruz, Mexico. Data pertaining to seedlings (0.20-1 m height), saplings $(>1 \mathrm{~m}$ height and $<5 \mathrm{~cm}$ DBH) and adult trees (>10 cm DBH) are presented. (DBH): diameter at breast height; $\left(\mathrm{H}^{\prime}\right)$ : Shannon-Wiener index, calculated for adult trees. Different letters denote significant differences between logging levels after Tukey's post hoc analysis $(P<0.05)$.

\begin{tabular}{|c|c|c|c|c|}
\hline \multirow{2}{*}{ Parameter } & \multicolumn{4}{|l|}{ Logging Level } \\
\hline & L1 & L2 & $\mathrm{H} 1$ & $\mathrm{H} 2$ \\
\hline \multirow[t]{2}{*}{ Coordinates } & $19^{\circ} 31^{\prime} 36^{\prime \prime} \mathrm{N}$ & $19^{\circ} 31^{\prime} 59^{\prime \prime} \mathrm{N}$ & $19^{\circ} 30^{\prime} 58^{\prime \prime} \mathrm{N}$ & $19^{\circ} 31^{\prime} 04^{\prime \prime} \mathrm{N}$ \\
\hline & $96^{\circ} 59^{\prime} 30^{\prime \prime} \mathrm{W}$ & $97^{\circ} 00^{\prime} 08^{\prime \prime} \mathrm{W}$ & $97^{\circ} 00^{\prime} 27^{\prime \prime} \mathrm{W}$ & $97^{\circ} 00^{\prime} 16^{\prime \prime} \mathrm{W}$ \\
\hline Altitude (m) & 1522 & 1630 & 1661 & 1651 \\
\hline Seedlings (no $\mathrm{m}^{-2}$ ) & $0.79 \pm 0.26$ & $1.17 \pm 0.24$ & $1.13 \pm 0.36$ & $0.79 \pm 0.16$ \\
\hline Seedling height (m) & $0.59 \pm 0.06$ & $0.46 \pm 0.05$ & $0.50 \pm 0.05$ & $0.39 \pm 0.05$ \\
\hline Saplings $\left(\right.$ no $\left.\mathrm{m}^{-2}\right)$ & $0.50 \pm 3.76$ & $0.39 \pm 1.61$ & $0.53 \pm 1.19$ & $0.43 \pm 1.01$ \\
\hline Adult trees (no ha ${ }^{-1}$ ) & $1158.33 \pm 26.48$ & $991.67 \pm 16.30$ & $1191.67 \pm 15.28$ & $1025.00 \pm 12.31$ \\
\hline Basal area $\left(\mathrm{m}^{2} \mathrm{ha}^{-1}\right)^{\prime}$ & $87.80 \pm 16.1^{\mathrm{a}}$ & $72.50 \pm 13.1^{a}$ & $44.86 \pm 8.59^{b}$ & $38.98 \pm 5.57^{b}$ \\
\hline $\mathrm{DBH}(\mathrm{cm})$ & $37.49 \pm 4.08$ & $34.99 \pm 3.89$ & $28.92 \pm 2.66$ & $30.00 \pm 2.68$ \\
\hline Canopy height (m) & $25.02 \pm 2.55$ & $24.95 \pm 2.00$ & $21.30 \pm 1.15$ & $23.28 \pm 0.51$ \\
\hline Canopy cover (\%) & $85.09 \pm 1.49$ & $88.43 \pm 1.26$ & $89.56 \pm 0.74$ & $85.92 \pm 0.76$ \\
\hline $\mathrm{H}^{\prime}$ & 2.69 & 2.86 & 3.11 & 2.85 \\
\hline
\end{tabular}


Fig. 1 - Density of tree stumps by diameter class in tropical montane cloud forest fragments with low ( $\mathrm{L} 1$ and $\mathrm{L} 2$ ) and high ( $\mathrm{L} 1$ and $L 2$ ) selective logging intensities in Veracruz, Mexico.
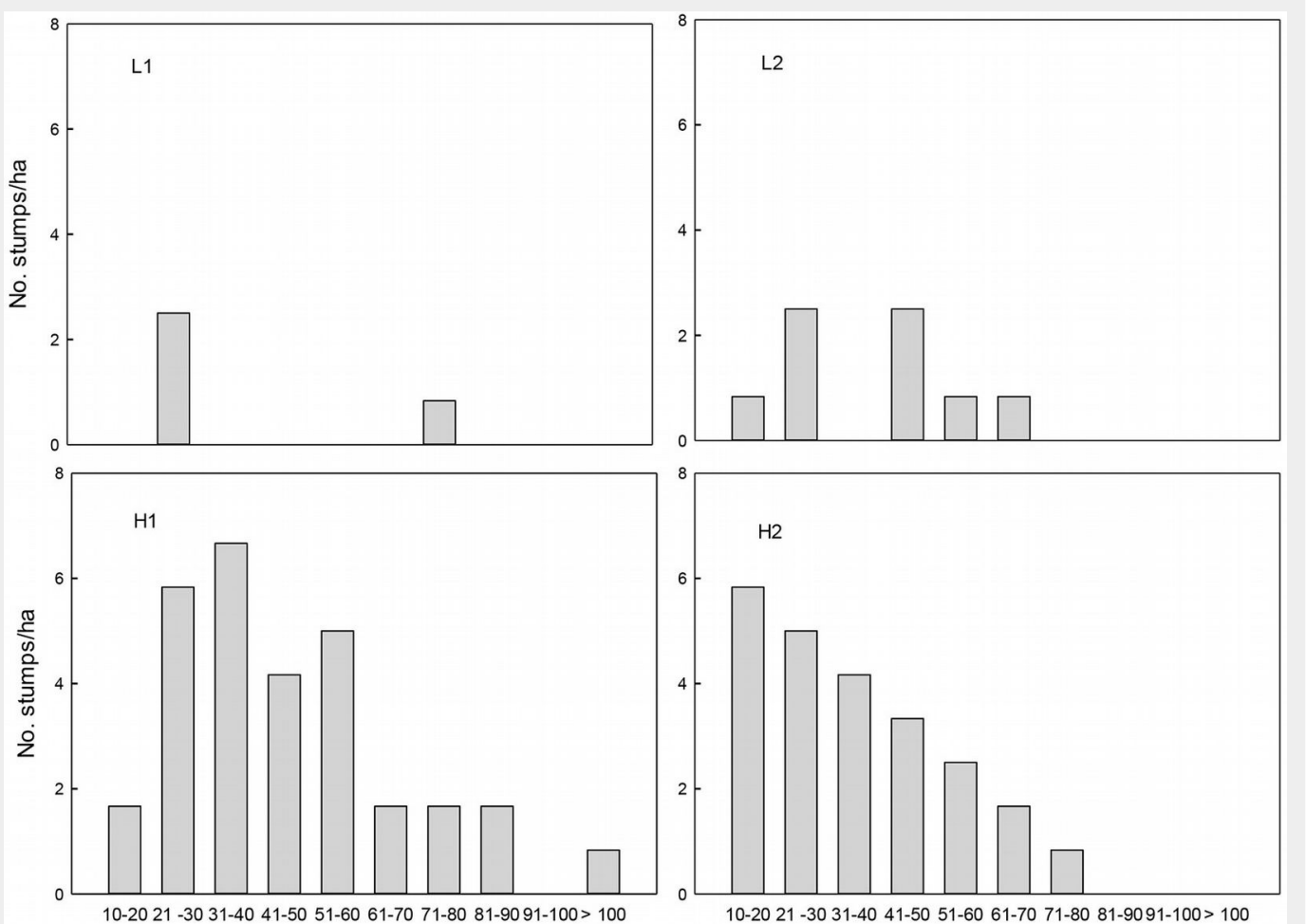

Diameter classes $(\mathrm{cm})$

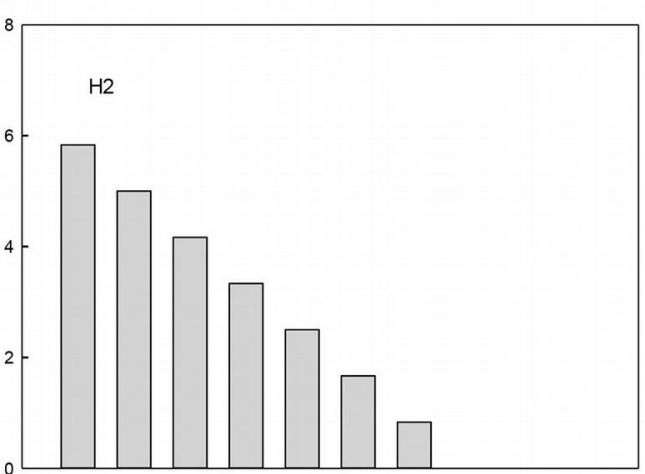

$10-2021-3031-4041-50$ 51-60 61-70 71-80 81-9091-100> 100 Diameter classes $(\mathrm{cm})$
Specimens were identified with the help of specialists and voucher specimens were deposited in the IE-XAL herbarium in Xalapa, Mexico. Most of the seedlings were only identified to genus due to the lack of morphological characteristics enabling further identification. Where previous information on the shade-tolerance of the species was available, these were classified into three groups: shade-intolerant or pioneer, intermediate and shade-tolerant (Tab. S1 in Supplementary material).

\section{Data analysis}

A timber extraction index was constructed based on the sum of three variables: the numbers of cut tree stumps, logs and kilns. Moreover, the tree stumps were also categorized into diametric size-classes. Since extraction data was recorded in only one sampling event per site, no measurements of variation were calculated. Based on the obtained values of the extraction index, the sites were grouped into two categories: low $(\mathrm{L})$ and high $(\mathrm{H})$ selective logging.

A mixed general linear model (GLM) was applied to evaluate the differences among the levels of extraction in terms of tree densities ( $\geq 10 \mathrm{~cm} \mathrm{DBH}), \mathrm{DBH}$, basal area and canopy coverage. The extraction intensity was considered a fixed factor within the model with two levels ( $L$ and $H$ ), while the site was included as random factor (Quinn \& Keough 2002). Adult tree density values were Box-Cox $(\lambda=0)$ transformed in order to comply with the assumptions of normality (Crawley 2002). To assess differences in the density of seedlings and saplings between the two extraction inten- sities, a generalized linear model was used with a log-link function and a Poisson type distribution (Quinn \& Keough 2002) using the software package SPSS ${ }^{\oplus}$ ver. 20.0 (IBM Corp., Armonk, NY, USA). Linear regression was performed to determine whether a relationship existed between canopy coverage and total density of seedlings. For this analysis, the density of seedlings was Box-Cox $(\lambda=0)$ transformed and the percentage of canopy coverage was arcsine square root transformed (Crawley 2002). This analysis was performed with the software MiniTab ${ }^{\circledast}$ ver. 16 (Minitab Inc., State College, PA, USA).

To evaluate the composition of the vegetation and determine species dominance, the importance value index (IVI) was calculated for trees with $\mathrm{DBH}>10 \mathrm{~cm}$. This index measures the ecological value of the species through the sum of three variables: relative number of individuals, relative frequency and relative dominance (basal area) per species (Mueller-Dombois 1974 see also Tab. S2 in Supplementary material). Relative values were calculated dividing the observed value of each species by the total of species.

To calculate the diversity of adult trees in each site, the Shannon-Wiener index was applied (Magurran 2004) using the software EstimateS 9.1.0 (Colwell 2013). In the case of regeneration, an index of diversity was not determined because many individuals could not be reliably identified to the species level. Similarity between tree species in the mature canopy and in the understory layer was evaluated in each site with the Morisita-Horn index. This index is based on abundances and is not affected by bias due to sample size (Magurran 2004). Relative abundance curves were generated per genus or per species in order to compare the community of adults with the regeneration.

\section{Results}

Structure and diversity of cloud forest after traditional selective logging

Based on the extraction index, the surveyed sites were classified into two selective logging intensities: low (L) and high (H). Index values were approximately three times lower in $L$ than in $H(L 1=7.5, L 2=$ 9.2, $\mathrm{H}_{1}=35$ and $\mathrm{H}_{2}=35$, respectively). In the $L$ sites, all of the tree stump diametric categories were underrepresented, as compared with the $\mathrm{H}$ sites (Fig. 1). The basal area of standing trees was significantly higher in $L$ than in $H$ sites $(F=11.35, d f=1$, $P=0.003)$. No significant differences were found between the extraction levels in terms of $\mathrm{DBH}$, density of adult individuals $(\mathrm{DBH}>10 \mathrm{~cm})$ and canopy coverage $(P$ $>0.05$ - Tab. 1). The distribution of diametric classes among all tree species of $\mathrm{DBH}$ $\geq 10 \mathrm{~cm}$ in the four sites followed an inverted J pattern, but many diametric classes were not present in the $\mathrm{H}$ sites (Fig. 2).

A total of 37 tree species were found over all sites, belonging to 32 genera and 25 families, of which 16 species are threatened and/or included in conservation priority lists (González-Espinosa et al. 2011). Of the species recorded in this study, eight are used for timber; three of these are endemic to Mexico (Quercus delgadoana, Q. sartorii and Turpinia insignis) and classified 

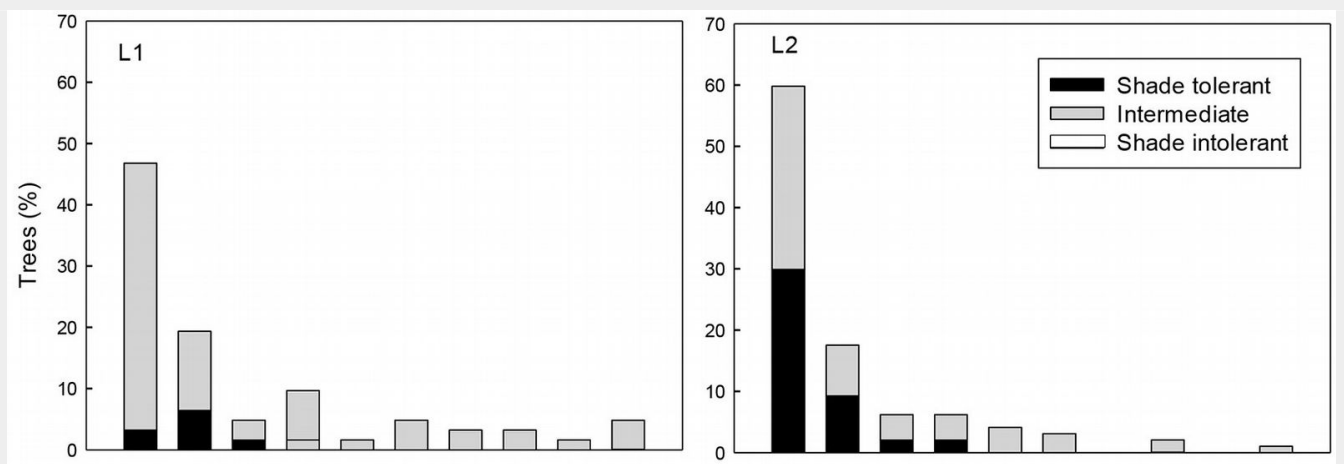

Fig. 2 - Percentage of trees $(\mathrm{DBH} \geq 5 \mathrm{~cm})$ classified according to shade tolerance (shade tolerant, intermediate and shade intolerant) in tropical montane cloud forest with low (L1 and L2) and high ( $\mathrm{H}_{1}$ and $\mathrm{H}_{2}$ ) selective logging intensities in Veracruz, Mexico.

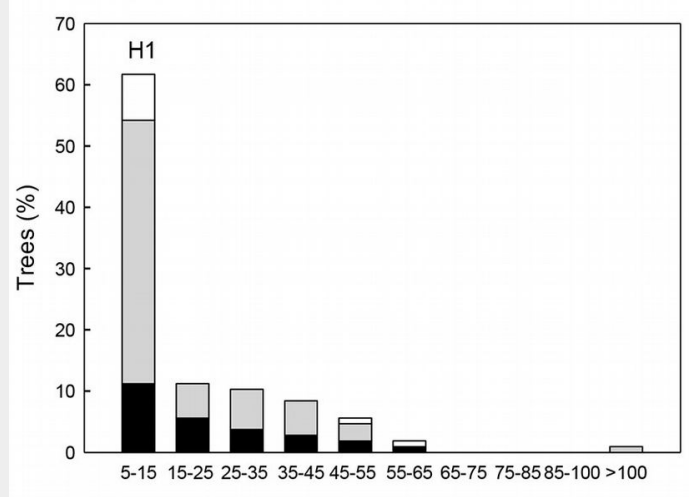

Diameter classes $(\mathrm{cm})$

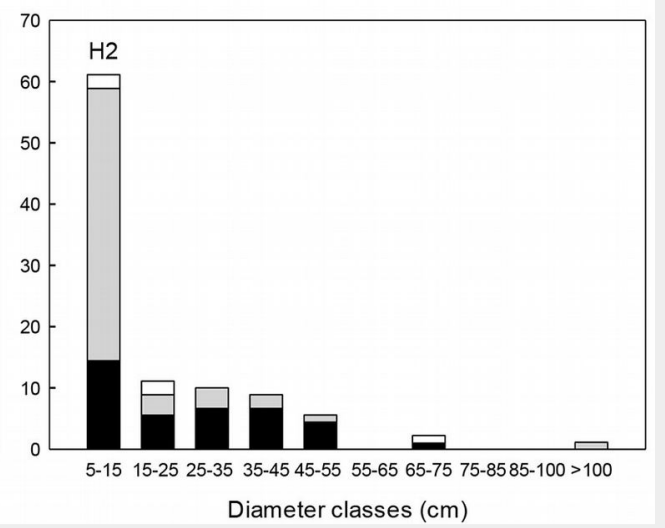

as threatened (González-Espinosa et al. 2011).

The genus Quercus was dominant in the canopy at all sites, with a higher dominance in the $L(56.4 \%$ and $67.4 \%)$ than in the $\mathrm{H}(39.9 \%$ and $60.2 \%)$ sites (Tab. S2 in supplementary material). Other dominant species at the $L$ sites were Carpinus caroliniana (IVI = 13.6), Liquidambar styraciflua (IVI = 11.3) and $\mathrm{T}$. insignis (IVI $=6.11$ ), while at the $\mathrm{H}$ sites these were Clethra macrophylla (IVI = 11.5), L. styraciflua (IVI = 11.1) and Zanthoxylum melanostictum (IVI $=7.9-$ Tab. S2 in the Supplementary material).

Of the 37 species recorded, 29 are reported in the literature within one of the three functional groups of shade-tolerance. Species of intermediate tolerance were the most abundant in all sites ( $\mathrm{L} 1=$ $87.1 \%, \mathrm{~L} 2=55.7 \%, \mathrm{H}_{1}=64.5 \%$ and $\mathrm{H}_{2}=$ $55.6 \%)$, followed by the shade-tolerant species ( $\mathrm{L} 1=12.9 \%, \mathrm{~L} 2=44.3 \%, \mathrm{H} 1=27.1 \%$ and $\mathrm{H}_{2}=40.0 \%$ - Fig. 2). Pioneer species were absent in the $\mathrm{L}$ sites and showed low relative abundance at the $\mathrm{H}$ sites ( $\mathrm{H} 1=8.4 \%$ and $\mathrm{H}_{2}=4.4 \%$ - Fig. 2).
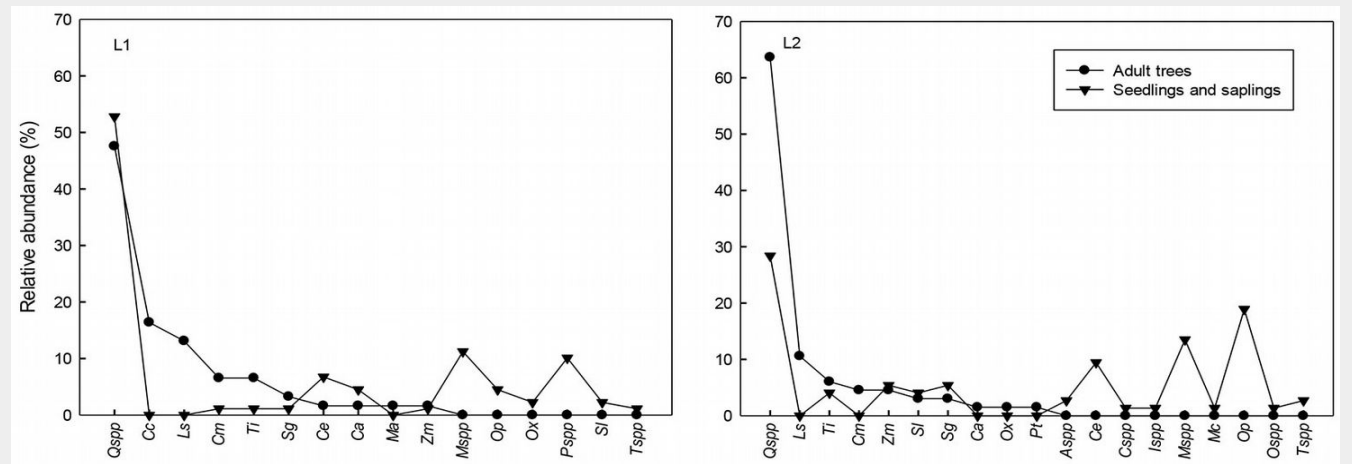

Fig. 3 - Relative abundance (\%) of adult trees (DBH $\geq$ $5 \mathrm{~cm})$ and regeneration (seedlings and saplings) in tropical montane cloud forest with low ( $L 1$ and $L 2$ ) and high ( $\mathrm{H}_{1}$ and $\left.\mathrm{H}_{2}\right)$ selective logging in Veracruz, Mexico. (Al): Alchornea latifolia; (Aspp): Ardisia spp.; (Bm): Bernardia macrocarpa; (Cc): Carpinus caroliniana; (Ce): Cinnamomum effusum;
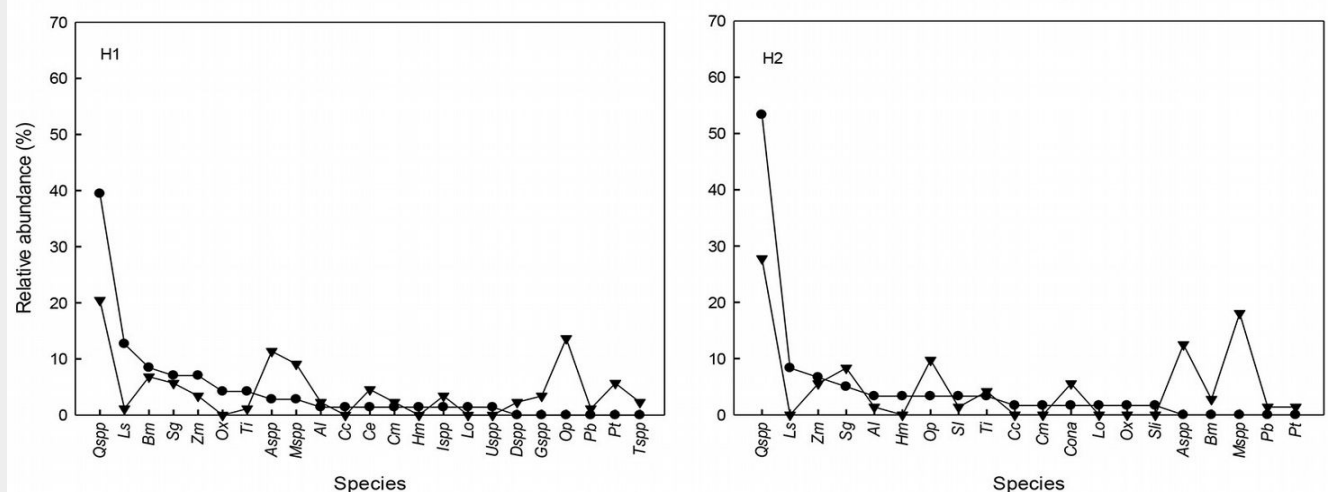

(Cspp): Citharexylum spp.;

(Cm): Clethra macrophylla; (Ca): Cojoba arborea; (Cona): Conostegia arborea; (Dspp): Deppea spp.; (Gspp): Guarea spp.; (Hm): Hedyosmum mexicanum; (Ispp): Inga spp.;

(Ls): Liquidambar styraciflua; (Lo): Lonchocarpus orizabensis; (Ma): Meliosma alba; (Mspp): Miconia spp.; (Mc): Myrsine coriacea; (Op): Ocotea psychotrioides; (Ox): Oreopanax xalapensis; (Ospp):

Osmanthus spp.; (Pb): Prunus brachybotrya; (Pt): Prunus tetradenia; (Pspp): Psychotria spp.; (Qspp): Quercus spp.; (SI): Saurauia leucocarpa; (Sg): Styrax glabrescens; (Sli): Symplocos limoncillo; (Tspp): Trophis spp.; (Ti): Turpinia insignis; (Uspp): Ulmus spp.; (Zm): Zanthoxylum melanostictum. 
Tree regeneration in traditionally logged cloud forests

Seedling and sapling densities did not differ between levels of extraction (seedlings: Wald $X^{2}=1.7, d f=1, P=0.19$; saplings: Wald $\left.\mathrm{X}^{2}=0.14, \mathrm{df}=1, \mathrm{P}=0.70\right)$. The mean seedling density per treatment $\left(0.97 \pm 2.46 \mathrm{~m}^{-2}-\right.$ mean $\pm 1 \mathrm{SE}$ ) was approximately double that of the saplings $\left(0.46 \pm 4.80 \mathrm{~m}^{-2}\right)$ in all of the sites (Tab. 1). The relationship between canopy coverage and seedling density was not significant in any site $\left(R^{2}\right.$ : $\mathrm{L}_{1}=0.05, \mathrm{~L} 2=0.46, \mathrm{H} 1=0.07, \mathrm{H}_{2}=0.11 ; \mathrm{P}>$ $0.05)$. The most abundant species among seedlings were Quercus spp. in all sites (four species representing together 50.5\%), followed by Ocotea psychotrioides (13\%) and Cinnamomum effusum (7.3\% - Fig. 3 ). Of the total number of seedlings and saplings, $76 \%$ belonged to the group of intermediate tolerance, $23 \%$ to that of shade-tolerance and $1 \%$ to the pioneers. According to the Morisita-Horn index, similitude among the genera and species of the canopy and those of the regeneration was relatively high in the four sites ( $L 1=0.86, \mathrm{~L} 2$ $=0.64, \mathrm{H}_{1}=0.69$ and $\mathrm{H}_{2}=0.71$ ).

\section{Discussion}

\section{Effects of selective logging on cloud} forest structure and diversity

Traditional selective logging is a common though illegal practice in the TMCF, with no records that could allow to quantify its intensity, frequency and extent of extraction. This study shows that the degraded TMCF in the studied plots differ in terms of the accumulated impact of selective timber extraction. In comparison with other TMCF in Mexico, even the sites with highest extraction $(\mathrm{H})$ showed a relatively low exploitation (Williams-Linera 2002, Ramírez-Marcial et al. 2003). In tropical montane rain forests subject to planned extraction, its intensity varies from 1 to 7 trees ha $^{-1}$ year ${ }^{-1}$; in Costa Rica, this is 1.8 trees ha year-1 at low intensity, 3 trees ha $^{-1}$ year $^{-1}$ at medium intensity and 5 trees ha $^{-1}$ year $^{-1}$ at high intensity (Aguilar-Amuchastegui \& Henebry 2007), while 2 to 7 trees ha $^{-1}$ year ${ }^{-1}$ are extracted in the Central African Republic (Decocq et al. 2014). The number of tree stumps per ha in this study was between 3.3 and 29.1. However, given that the values reported are cumulative, it is likely that the actual annual rate may be less than the figures reported for other countries. Even in the sites with higher selective logging $\mathrm{H}$ ), a high basal area value has been maintained that is still within the interval reported for mature or conserved TMCF. For the primary TMCF of Costa Rica, basal area values of $60.7 \mathrm{~m}^{2}$ ha-1 have been reported (Kappelle et al. 1996), with values of 29.6 to $40.7 \mathrm{~m}^{2} \mathrm{ha}^{-1}$ reported in the conserved TMCF of Peru (Ledo et al. 2012).

While the TMCF are characterized by high beta diversity and elevated structural and compositional heterogeneity (Williams-Linera 2002), the overall richness of trees found in this study (13 to 18 species per site) was lower than that reported for other TMCF in Mexico (41 to 56 species González-Espinosa et al. 1991, Muñiz-Castro et al. 2012, Fortanelli-Martínez et al. 2014). The lower richness found could be the result of species local extinction, due to the legacy effects of historical over-extraction which led to the long-term reduction of diversity (Farwig et al. 2008). In this study, the greatest diversity of adult trees was recorded in the forest with the highest intensity of extraction ( $\mathrm{H} 1$ ); however, this stems from the lower dominance of shadetolerant species and the greater contribution of pioneer species. The opening of clearings by extraction can reduce the competitive exclusion of shade-tolerant species, thus favoring pioneer species (Sheil \& Burslem 2003).

\section{Chronic selective logging: threat to} cloud forest regeneration?

The density of seedlings and saplings found below the stands was unaffected by the intensity of logging and was lower than that reported in other TMCF with illegal selective logging in Mexico (1-5 stems $\mathrm{m}^{-2}-$ Alvarez-Aquino 2001) but similar to that reported in tropical montane forests with high selective logging in East Africa (0.51.93 stems $\mathrm{m}^{-2}$ - Kirika et al. 2010). Regeneration in the studied sites was mainly represented by seedlings $<1 \mathrm{~m}$ in height, while saplings were less represented. This indicates that around $50 \%$ of the seedlings do not reach the sapling stage. However, the survival of tree seedlings could be affected by biotic and abiotic factors at the site level and requires further evaluation.

The species composition of seedlings and saplings was dominated by Quercus spp., the group of greatest interest for the production of firewood and charcoal. Growth and survival of seedlings of the genus Quercus is favored by moderate disturbance of the TMCF or partial opening of the canopy (Galindo-Jaimes et al. 2002, Guariguata \& Sáenz 2002) and simulated conditions of intermediate shade (RamírezMarcial et al. 2003). Oaks also have a high capacity of resprouting from the root, allowing for their persistance in degraded sites (Johnson et al. 2009). In contrast, the lower regeneration abundance of species with higher requirements of solar radiation (e.g., L. styraciflua and C. caroliniana) could be limited by the elevated canopy coverage observed at the study sites (85.09$89.56 \%$ ). This could be due to a relatively fast canopy closure that masks the effect of selective logging on canopy (ToledoAceves et al. 2009).

The high similarity found between the diversity of adults and that of regeneration could be the result of the fact that the dominant species make a greater contribution to the Morisita-Horn similarity index, thus leading to underestimation of the effect of less abundant species (Magurran 2004). For example, species such as Me- liosma alba, Lonchocarpus orizabensis, Hedyosmum mexicanum, Symplocos limoncillo and UImus mexicana were not abundant in the canopy and were not recorded in the regeneration. The little or null regeneration of rare species in the canopy can be related to various causes that include, among others: a low density of adult individuals that hampers their sexual reproduction, high rates of seed predation, low rates of germination, damage by pathogens or herbivores following germination and excessive competition with herbaceous plants or lianas (Mostacedo \& Fredericksen 1999, Harms \& Paine 2003). Moreover, some tree populations have locally disappeared in the study region because of uncontrolled exploitation. These are mainly shade-tolerant hardwood species such as Taxus globosa and Ocotea disjunta (Paré \& Gerez 2012). However, more investigations are needed to understand whether the low abundance of the rare species is due to their patterns of natural distribution in tropical forests (Harms \& Paine 2003) or is a consequence of over extraction.

\section{Planned forestry management in tropical montane cloud forest}

The development of effective forest management strategies in TMCF is complex due to its high heterogeneity and diversity and the insufficient availability of ecological information on the attributes and requirements of each species. We focused on the group Quercus spp. because: (a) these are the trees of choice for the production of firewood and charcoal; (b) their dominance in the canopy with several species; (c) their dominance in the regeneration; (d) their high capacity for resprouting; and (e) information is available about their management in other regions (Guariguata \& Sáenz 2002, Götmark 2009). Planning of selective extraction of Quercus spp. for the production of firewood and charcoal could be a viable strategy, as partial cutting could also favor the growth of the remnant trees (Götmark 2009). In other forestry systems, it has been reported that extraction stimulates residual tree growth, germination and recruitment (Guariguata \& Sáenz 2002, Duah-Gyamfi et al. 2014).

At the landscape scale, low impact exploitation could be a viable option if complemented by the maintenance of nofelling zones within the forest (retention forestry) in order to increase and diversify tree regeneration. A scenario of low disturbance typical of fuel wood extraction in the TMCF was simulated by Golicher \& Newton (2007), who found only slight fluctuations over time in the total number of individuals and basal area. Furthermore, charcoal production has been associated with forest degradation, though not necessarily cause deforestation (Chidumayo \& Gumbo 2013). Traditional selective logging in TMCF contributes to the provision of firewood and charcoal, which play an important role in energy provision to local 
human populations. Considering the high value of TMCF for biodiversity conservation and the increasing demand for fuel wood from tropical forests, it is essential that the planned management of TMCF includes practices such as enrichment plantations using rare and vulnerable species in order to secure the maintenance of their populations.

\section{Conclusions}

In this study, traditional selective logging in the TMCF varied across sites in terms of extraction intensity, but this variation did not impact the density and composition of tree regeneration. Oaks (Quercus spp.) were the dominant species in both the canopy and the regeneration. Tree species which were rare in the canopy and threatened at regional level were not represented in the regeneration. Therefore, we recommend the establishment of conservation areas within the TMCF with the aim of maintaining its high tree diversity and counterbalancing the detrimental effects of selective logging at the landscape level. The results of this study suggest that planned selective logging (in particular on species belonging to the genus Quercus) could be a viable management strategy compatible with the maintenance of these priority forests.

\section{Acnowledgements}

POC carried out field measurements, statistical analysis, and manuscript writing, TTA conceived the study, assisted with statistical analysis and wrote the manuscript, FLB contributed to the experimental design and drafting the manuscript, PGF contributed to the experimental design and drafting the manuscript. POC thanks CONACYT for the grant awarded (no. 280416) for a Masters degree.

This project was funded by INECOL A.C. (no. 20030-11218). We thank R. Hernández, T. Guillen, F. Lorea, C. Gallardo, P. Barret and R. García for permission to work on their properties. We thank C. Gallardo for species identification and $M$. Sangabriel and $\mathrm{A}$. Cortés for their help with fieldwork and K. Macmillan for English revision. L. Sánchez and $M$. Bonilla provided helpful comments to a previous version of the manuscript.

\section{References}

Alvarez-Aquino C (2001). Regeneration of tree species in Mexican cloud forest. PhD Thesis, University of Edinburgh, Scotland, UK, pp. 199. Aguilar-Amuchastegui N, Henebry GM (2007). Assessing sustainability indicators for tropical forests: spatio-temporal heterogeneity, logging intensity, and dung beetle communities. Forest Ecology and Management 253: 56-67. - doi: 10.1016/j.foreco.2007.07.004

Carreño-Rocabado G, Peña-Claros M, Bongers F, Alarcón A, Licona JC, Poorter L (2012). Effects of disturbance intensity on species and functional diversity in a tropical forest. Journal of Ecology 100: 1453-1463. - doi: 10.1111/j.1365-2745. 2012.02015.x

Chazdon RL (2003). Tropical forest recovery: legacies of human impact and natural disturbances. Perspectives in Plant Ecology, Evolution and Systematics 6: 51-71. - doi: 10.1078/14 33-8319-00042

Chidumayo EN, Gumbo DJ (2013). The environmental impacts of charcoal production in tropical ecosystems of the world: a synthesis. Energy for Sustainable Development 17: 86-94. - doi: 10.1016/j.esd.2012.07.004

Clark JA, Covey KR (2012). Tree species richness and the logging of natural forests: a meta-analysis. Forest Ecology and Management 276: 146153. - doi: 10.1016/j.foreco.2012.04.001

Colwell RK (2013). EstimateS (Statistical estimation of species richness and shared species from samples). Version 9.1.0 University of Connecticut, CT, Storrs, USA. [online] URL: http:// viceroy.eeb.uconn.edu/estimates/

CONABIO (2010). El bosque mesófilo de montaña en México: Amenazas y oportunidades para su conservación y manejo sustentable. [Cloud forest in Mexico: threats and opportunities for their conservation and sustainable management]. Comisión Nacional para el Conocimiento y Uso de la Biodiversidad (Toledo Aceves T ed), CONABIO, Mexico, pp. 196.

Crawley M (2002). Statistical computing, an introduction to data analysis using S-Plus. John Wiley and Sons Ltd, Chichester, UK, pp. 772.

Decocq G, Beina D, Jamoneau A, Gourlet-Fleury S, Closse-Kopp D (2014). Don't miss the forest for the trees! Evidence for vertical differences in the response of plant diversity to disturbance in a tropical rain forest. Perspectives in Plant Ecology, Evolution and Systematics 16: 279-287. - doi: 10.1016/j.ppees.2014.09.001

Duah-Gyamfi A, Swaine EK, Adam KA, Pinard MA, Swaine MD (2014). Can harvesting for timber in tropical forest enhance timber tree regeneration? Forest Ecology and Management 314: 26-37. - doi: 10.1016/j.foreco.2013.11.025

Farwig N, Sajita N, Schaab G, Böhning-Gaese K (2008). Human impact diminishes seedling species richness in Kakamega Forest, Kenya. Basic and Applied Ecology 9: 383-391. - doi: 10.1016/j. baae.2007.05.006

FAO (2015). Global Forest Resources Assessment 2015. How are the world's forests changing? FAO, Rome, Italy, pp. 56.

Fortanelli-Martínez J, García-Pérez J, Castillo-Lara $\mathrm{P}$ (2014). Estructura y composición de la vegetación del bosque de niebla de Copalillos, San Luis Potosí, México. [Structure and composition of cloud forest vegetation in Copalillos, San Luis Potosí, Mexico]. Acta Botánica Mexicana 106: 161-186. - doi: 10.21829/abm106.2014. 218

Galindo-Jaimes L, González-Espinosa M, Quintana-Ascencio P, García-Barrios L (2002). Tree composition and structure in disturbed stands with varying dominance by Pinus spp. in the highlands of Chiapas, Mexico. Plant Ecology 162: 259-272. - doi: 10.1023/A:1020309004233

Gibson L, Lee TM, Koh LP, Brook BW, Gardner TA, Barlow J, Peres CA, Bradshaw CJA, Laurance WF, Lovejoy TE, Sodhi NS (2011). Primary forests are irreplaceable for sustaining tropical biodiversity. Nature 478 (7369): 378-381. - doi: $10.1038 /$ nature10425
Golicher D, Newton AC (2007). Applying succession models to the conservation of tropical montane forest. In: "Biodiversity loss and conservation in fragmented forest landscapes. The forests of montane Mexico and temperate South America". CABI, Wallingford, Oxfordshire, UK, pp. 200-222. [online] URL: http:// books.google.com/books?id=BPoRpfblk-QC González-Espinosa M, Quintana-Ascencio PF, Ramírez-Marcial N, Gaytán-Guzmán P (1991). Secondary succession in disturbed Pinus-Quercus forests in the highlands of Chiapas, Mexico. Journal of Vegetation Science 2: 351-360. - doi: $10.2307 / 3235927$

González-Espinosa M, Meave JA, Lorea-Hernández F, Ibarra-Manríquez G, Newton AC (2011). The red list of mexican cloud forest trees. Fauna and Flora International, Cambridge, UK, pp. 149.

Götmark F (2007). Careful partial harvesting in conservation stands and retention of large oaks favour oak regeneration. Biological Conservation 140: 349-358. - doi: 10.1016/j.biocon. 2007.08.018

Götmark F (2009). Experiments for alternative management of forest reserves: effects of partial cutting on stem growth and mortality of large oaks. Canadian Journal of Forest Research 39: 1322-1330. - doi: 10.1139/Xo9-045

Guariguata MR, Pinard M (1998). Ecological knowledge of regeneration from seed in neotropical forest trees: Implications for natural forest management. Forest Ecology and Management 112: 87-99. - doi: 10.1016/S0378-1127 (98)00318-1

Guariguata MR, Sáenz GP (2002). Post-logging acorn production and oak regeneration in a tropical montane forest, Costa Rica. Forest Ecology and Management 167: 285-293. - doi: 10.1016/S0378-1127(01)00700-9

Haeckel I (2006). Firewood use, supply, and harvesting impact in cloud forests of central Veracruz, Mexico. Bachelor thesis, Columbia University, New York, NY, USA, pp. 60.

Harms KE, Paine CET (2003). Regeneración de los árboles tropicales e implicaciones para el manejo de bosques naturales [Regeneration of tropical trees and implications for the management of natural forests]. Ecosistemas 12 (3): 16 . [online] URL: http://www.revistaecosistemas. net/index.php/ecosistemas/article/view/226

Imai N, Seino T, Aiba SI, Takyu M, Titin J, Kitayama K (2012). Effects of selective logging on tree species diversity and composition of Bornean tropical rain forests at different spatial scales. Plant Ecology 213: 1413-1424. - doi: 10.1007/s11258-012-0100-y

Johnson PS, Shifley SR, Rogers R (2009). The ecology and silviculture of oaks. CABI Publishing, Wallingford, Oxford, UK, pp. 600. [online] URL: http://books.google.com/books?id=ojGjlv ebb_EC

Kappēlle M, Geuze T, Leal M, Cleef AM (1996). Successional age and forest structure in a Costa Rican upper montane Quercus forest. Journal of Tropical Ecology 12: 681-698. - doi: 10.1017/S0266467400009871

Kirika JM, Böhning-Gaese K, Dumbo B, Farwig N (2010). Reduced abundance of late-successional trees but not of seedlings in heavily compared with lightly logged sites of three East 
African tropical forests. Journal of Tropical Ecology 26: 533-546. - doi: 10.1017/So26646741000 0283

Kozlowski T (2002). Physiological ecology of natural regeneration of harvested and disturbed forest stands: implications for forest management. Forest Ecology and Managment 158: 195221. - doi: 10.1016/S0378-1127(00)00712-X

Ledo A, Condés S, Alberdi I (2012). Forest biodiversity assessment in Peruvian Andean Montane cloud forest. Journal of Mountain Science 9: 372-384. - doi: 10.1007/s11629-009-2172-2

Magurran A (2004). Measuring biological diversity. Blackwell Science. Oxford, UK, pp. 256.

Martin PA, Newton AC, Pfeifer M, Khoo M, Bullock JM (2015). Impacts of tropical selective logging on carbon storage and tree species richness: A meta-analysis. Forest Ecology and Management 356: 224-233. - doi: 10.1016/j.for eco.2015.07.010

Mostacedo CB, Fredericksen TS (1999). Regeneration status of important tropical forest tree species in Bolivia: assessment and recommendations. Forest Ecology and Management 124: 263-273. - doi: 10.1016/S0378-1127(99)00076-6

Mueller-Dombois D (1974). Aims and methods of vegetation ecology. John Wiley and Sons, New York, USA, pp. 547.

Muñiz-Castro MA, Williams-Linera G, MartínezRamos M (2012). Dispersal mode, shade tolerance, and phytogeographical affinity of tree species during secondary succession in tropical montane cloud forest. Plant Ecology 213:339353. - doi: 10.1007/s11258-011-9980-5

Muñoz-Villers LE, Lopez-Blanco J (2008). Land use/cover changes using Landsat TM/ETM images in a tropical and biodiverse mountainous area of central-eastern Mexico. International Journal of Remote Sensing 29: 71-93. - doi: 10.1080/01431160701280967

Nabe-Nielsen J, Severiche W, Fredericksen T,
Nabe-Nielsen LI (2007). Timber tree regeneration along abandoned logging roads in a tropical Bolivian forest. New Forests 34: 31-40. - doi: 10.1007/s11056-006-9035-2

Paré L, Gerez P (2012). Anexo 3. In: “Al filo del agua: cogestión de la subcuenca del río Pixquiac, Veracruz". [At the water's edge: comanagement on the Pixquiac watershed, Veracruz] (Paré L, Gerez P eds). SEMARNAT / INE / Juan Pablos Editores, Mexico, pp. 303-318.

Putz FE, Zuidema PA, Synnott T, Peña-Claros M, Pinard MA, Sheil D, Zagt R (2012). Sustaining conservation values in selectively logged tropical forests: the attained and the attainable. Conservation Letters 5: 296-303. - doi: 10.1111/j. 1755-263X.2012.00242.X

Quinn G, Keough MJ (2002). Experimental design and data analysis for biologists. Cambridge University Press, Cambridge, UK, pp. 537. [online] URL: http://books.google.com/ books?id=VtU3-y7LaLYC

Ramírez-Marcial N, González-Espinosa M, Williams-Linera G (2001). Anthropogenic disturbance and tree diversity in montane rain forests in Chiapas, Mexico. Forest Ecology and Management 154: 311-326. - doi: 10.1016/S03781127(00)00639-3

Ramírez-Marcial N, Camacho-Cruz A, GonzálezEspinosa M (2003). Guía para la propagación de especies leñosas nativas de Los Altos y montañas del norte de Chiapas [Guide for propagation of native wood species from Los Altos and Northern mountains of Chiapas]. El Colegio de la Frontera Sur, Chiapas, Mexico, pp. 39.

Rüger N, Williams-Linera $G$, Kissling WD, Huth A (2008). Long-term impacts of fuelwood extraction on a tropical montane cloud forest. Ecosystems 11: 868-881. - doi: 10.1007/s10021-008-91 66-8

Scatena FN, Bruijnzeel LA, Bubb P, Das S (2010). Setting the stage. In: "Tropical Montane Cloud
Forests Science for Conservation and Management" (Bruijnzeel LA, Scatena FN, Hamilton LS eds). Cambridge University Press, Cambridge, UK, pp. 3-13. [online] URL: http://books.goog le.com/books?id=N6FkwMnSX8EC

Sheil D, Burslem DF (2003). Disturbing hypotheses in tropical forests. Trends in Ecology and Evolution 18: 18-26. - doi: 10.1016/S0169-5347 (02)00005-8

Toledo-Aceves T, Purata Velarde S, Peters C (2009). Regeneration of commercial tree species in a logged forest in Selva Maya, Mexico. Forest Ecology and Management 258: 24812489. - doi: 10.1016/j.foreco.2009.08.033

Toledo-Aceves T, Meave JA, González-Espinoza M, Ramírez-Marcial N (2011). Tropical montane cloud forests: current threats and opportunities for their conservation and sustainable management in Mexico. Journal of Environmental Management 92: 974-981. - doi: 10.1016/j.jenv man.2010.11.007

Williams-Linera G (2002). Tree species richness complementarity, disturbance and fragmentation in a Mexican tropical montane cloud forest. Biodiversity Conservation 11: 1825-1843. doi: 10.1023/A:1020346519085

\section{Supplementary Material}

Tab. S1 - List of tree species (DBH>10 cm) in four sites of tropical montane cloud forest with traditional selective logging in Veracruz, Mexico.

Tab. S2 - Importance Value Index (IVI) of trees $(\mathrm{DBH}>10 \mathrm{~cm}$ ) in tropical montane cloud forest sites with low (L1 and L2) and high ( $\mathrm{H}_{1}$ and $\mathrm{H}_{2}$ ) selective logging in Veracruz, Mexico.

Link: Ortiz_1937@supplo01.pdf 